Article

\title{
Financing Climate Change Adaptation: International Initiatives
}

\author{
Govinda R. Timilsina
}

check for

updates

Citation: Timilsina, G.R. Financing Climate Change Adaptation: International Initiatives. Sustainability 2021, 13, 6515. https://doi.org/ $10.3390 /$ su13126515

Academic Editors: Adriana Del Borghi and Michael McAleer

Received: 23 March 2021

Accepted: 3 June 2021

Published: 8 June 2021

Publisher's Note: MDPI stays neutral with regard to jurisdictional claims in published maps and institutional affiliations.

Copyright: (C) 2021 by the author. Licensee MDPI, Basel, Switzerland. This article is an open access article distributed under the terms and conditions of the Creative Commons Attribution (CC BY) license (https:/ / creativecommons.org/licenses/by/ $4.0 /)$.
Senior Economist, World Bank, Washington, DC 20433, USA; gtimilsina@worldbank.org

\begin{abstract}
Climate change adaptation is one of the main strategies to address global climate change. The least developed countries and the small island states that lack financial resources to adapt to climate change are the most vulnerable nations to climate change. Although it would be more economical to adapt to climate change compared to the anticipated damage of not doing so, the demand for capital is estimated to range to hundreds of billions. The crucial question is how to manage investments to adapt to climate change globally. This study provides an overview of existing international provisions on climate finance for adaptation. It includes provisions through international financial institutions, United Nations agencies, bilateral and multilateral channels, and the private sector. It also explores how private sector finance can be further attracted to invest in climate change adaptation.
\end{abstract}

Keywords: climate change; climate finance; climate change adaptation; climate resilient economic development

\section{Introduction}

The debate on climate change risks and adaptation has intensified in recent times. In the past, international negotiations on climate change, particularly at the Conference of Parties (COP) to the United Nations Framework Convention on Climate Change (UNFCCC), focused more on limiting the growth of greenhouse gas (GHG) concentrations. In the past, climate change adaptation did not get much attention because of numerous uncertainties related to timing and levels of impact. However, two recent phenomena have taken much attention from policymakers and climate negotiators. First, global emissions and, therefore, the concentration of GHGs have increased continuously despite the fact that climate change negotiation started 30 years ago, and the UNFCCC has urged the global stakeholders to act urgently since its formation in 1992 [1]. Second, initial indications of climate change are visible-extreme weather events are on the rise both in terms of frequency and intensity [2-4]. Therefore, there exists a consensus among most policymakers around the world that both climate change mitigation and adaptation should go hand in hand. It is also crucial to incentivize all countries worldwide to participate in efforts to combat climate change. Many countries, which are severely affected by climate change, do not contribute much to it. For example, small island states are most vulnerable to climate change, but their GHG emissions are insignificant compared to global emissions. On the other hand, countries (or groups of countries), which are large GHG emitters (e.g., China, United States, India, Brazil, Russia, Saudi Arabia, European Union), are also vulnerable to climate change.

Climate change is happening, as reflected by several weather- and climate-related events, such as the increased frequency and intensity of hurricanes and forest fires, and the high frequency of droughts causing loss of agriculture productivity in various parts of the world. In order to minimize the losses from these impacts, measures should be undertaken that help the ecosystem to adjust to these impacts, such as drought-resistance crop varieties. At the same time, new infrastructure (e.g., bridges, hydropower plants), settlements in the coastal areas, and developments in the low-lying areas should adopt measures to ensure their resilience against climate change-induced severe activities. 
The importance of climate change adaptation has also increased due to the pace of economic growth and urbanization both in new emerging economies and developing countries. Infrastructure development (e.g., roads, bridges, power plants, and transmission lines) and urbanization (i.e., compact building structures) are irreversible; once they are built, it would be too expensive to change. It creates an infrastructure lock-in. Therefore, climate change adaptation should be taken into account when infrastructures are being built for the first time. The development of climate-resilient urban infrastructure, along with the rapid rate of urbanization, is a critical challenge in the developing world at present. Some recent studies such as Hallegatte et al. (2019) [4] also economically justify climateresilient infrastructure investment, claiming that the economic benefits of climate change adaptation would be four times as high as its costs.

One key challenge to climate change adaptation is financing. Lack of finance is one of the main factors behind slow economic growth in developing countries. While many developing countries are striving to get the necessary funding for their basic infrastructural and human needs, how can they afford climate-resilient infrastructure, which requires higher upfront investment? This implies that developing countries need the increased financial resources for climate change adaptation to come through additional funding (i.e., in addition to the traditional overseas development assistance).

The recent trends of climate finance indicate that much of the climate finance (more than $80 \%$ ) committed to date has gone towards climate change mitigation activities (see, e.g., MDB, 2019 [5]). The smaller share of climate finance going towards adaptation can be attributed to two reasons. First, results from mitigation investment can be realized now; for example, investments in energy efficiency improvements offer immediate energy cost savings. On the other hand, the results of investment in climate change adaptation might be beneficial in the future but not necessarily immediately, although some investment benefits can be seen in the short-term as well. For example, investments in flood control or droughtresistant seeds can be realized now because these are existing problems. The second reason is that public sector climate finance for climate change mitigation also leverages private sector finance. The private sector financing of clean energy technology is ever increasing. However, climate change adaptation is a public good; the private sector does not have an incentive to finance climate change adaptation unless it is directly impacted. We will discuss this issue later in this paper. For these reasons, generating enough financing for climate change adaptation is challenging. However, the private sector is being encouraged through various means to contribute to climate change adaptation financing. For example, international financial institutions, bilateral and multilateral development agencies, and philanthropic organizations have made commitments towards climate change adaptation and resilience financing. The Green Climate Fund under the UNFCCC has committed to allocate half of its finances to climate change adaptation and resilience. The World Bank has developed its action plan on climate change adaptation and resilience [3], under which it plans to spend USD 50 billion over the next five years (2020-2025). In a third-round survey conducted by Heinrich Boll Stiftung North America in 2018 to track climate change adaptation funding, Watson and Schalatek (2019) [6] reports that the World Bank's Pilot Program for Climate Resilience (PPCR) is the largest window to finance climate change adaptation and resilience. In its new plan to contribute to international climate finance, the UK government has decided to balance mitigation and adaptation when allocating its international climate finance commitment [7]. Yet, climate change adaptation has not become common practice in infrastructure projects in many countries.

This paper aims to reflect on how climate change adaptation and resilience financing is unfolding globally. Currently, the information on climate change adaptation financing is scattered among various sources. There does not exist a comprehensive document that can provide an overall picture of the status of climate change adaptation and resilience financing-who is providing the funding, who is executing/administrating it, and where the funding is going. This situation creates an inefficiency through an overlapping of funding for the same sort of activities from various donors, while critical areas are not 
getting access to it. The contribution of this paper is that it brings this information together and provides a comprehensive picture of the current status of climate change adaptation financing. The paper is expected to be informative and useful to an audience that is not familiar with climate change adaptation financing.

The paper is organized as follows. The next section presents some estimations of the financial need for climate change adaptation based on existing literature. Section 3 presents the sources of climate change finance, various funding windows/mechanisms/facilities, and agencies to execute climate change finance. It includes financing through Multilateral Development Banks, United Nations Agencies, bilateral and multilateral channels, and the private sector. Section 4 further explains the private sector's role in financing climate change adaptation. Finally, Section 5 draws the key conclusions.

\section{Financial Need for Climate Change Adaptation}

How much investment would be needed and who will finance it are crucial questions. Answering them, however, is difficult because of the huge uncertainty with regard to climate change impacts and the required level of adaptation. There have been attempts to estimate the amount of investment needed to finance climate change adaptation. IPCC (2014) [8] presents some earlier estimations of the global costs or investment needed for climate change adaptation. However, these estimates vary significantly because of different methodologies used for the estimations, different sectors covered in the estimations, and also different time-horizons considered for the estimations. Moreover, the wider variations of costs also reflect uncertainties involved with climate change impacts and adaptation.

One early study to estimate the investment needed for climate change adaptation or building climate change resiliency is (UNFCCC, 2007) [9]. This study estimates that the global investment demand to adapt to climate change in 2030 could amount to between USD 50 billion and USD 170 billion (2005 price). Of this amount, the study estimates, USD 14 billion is required for agriculture, forestry, and fisheries, USD 11 billion for water supply systems, USD 5 billion to cope with increased diseases due to climate change, USD 11 billion for coastal area protection, and USD 8-130 billion for building climate change resilient infrastructure. These estimates are indicative only; the sectoral estimates are not comparable as they use different IPCC scenarios for the baseline.

Another early study that estimates investment needed to adapt to climate change is World Bank (2010) [10]. This study estimates that the world would need USD 70-100 billion annually between 2010 and 2050 to adapt to climate change even if the temperature rise is maintained at 2 degrees Celsius warmer than the pre-industrial period. This amount is relatively low if compared to global economic output (GDP), which is $0.17 \%$. On a regional basis, for both climate scenarios, the East Asia and Pacific Region would need the highest costs because the region is projected to be the most vulnerable to climate change. Three most vulnerable areas in this region-climate resilience infrastructure in the coastal zone, and water supply and flood protection-require the highest levels of investment to adapt to climate change. In relative terms (i.e., climate adaptation cost as the percentage of GDP), the cost of building climate resiliency would be highest in Sub-Saharan Africa.

A study commissioned by the United Nations Environmental Program (UNEP, 2016) [11] estimates that the annual requirement for climate change adaptation and resilience investment could vary between USD 140 and 300 billion by 2030 .

More recently, the World Bank estimated investment demand for building climateresilient infrastructure [4]. The study estimated that building climate-resilient infrastructure in the power, water and sanitation, and transport sectors in low- and middle-income countries will require between 11 to 65 billion USD a year by 2030. Building climateresilient basic infrastructure would increase the total investment need in these sectors only by 3 percent. The study also showed that investing one US dollar in these sectors for climate resiliency would benefit four US dollar by avoiding the potential damages faced by a lack of climate change adaptation. 
Please note the variations in the estimates of financial need for climate change adaptation made at various points in time. Whether the estimates were made in the 1990s or recently, large variations in each estimate exist. This indicates the level of uncertainty surrounding climate change impacts and adaptation. Further investigations and analyses are needed to narrow down these variations.

As mentioned above, the estimations of investment needs may not be precise, but all these estimations indicate one indisputable conclusion: the investment required for climate change adaptation is large. Since the most vulnerable countries to climate change are those low-income or poor countries, these countries will not be able to generate the necessary finances to address the challenges caused by climate change. This fact is acknowledged by international communities. This is the main agenda of negotiations and agreements in the several annual meetings of the Conference of Parties (COP) of the UNFCCC. There is an understanding under the UNFCCC negotiations or in any other global discussions (such as World Economic Forum, G20 meetings) that industrialized economies need to help developing countries to finance climate change adaptation. Therefore, international communities have developed a large number of windows to finance climate change adaptation activities in developing countries. This study presents these financial windows briefly.

\section{Climate Change Adaptation: Sources, Institutions, and Mechanisms}

This section underscores sources of finance for climate change adaptation, the institutions that administer the funds and vehicles or mechanisms through which the funds are distributed to climate change adaptation activities. As far as the sources of funding are concerned, the ultimate sources are governments, international development agencies, and the private sector, which contributes either for business or philanthropic purposes. There exists much overlapping between these sources, and determining the actual flow of climate change adaptation finance originating from particular sources is complex. For example, multilateral development banks (MDBs) use their resources or specific trust funds created by their donors for climate financing. Note, however, that their resources can consist of their earnings or contributions by their board member countries. Similarly, the private sector also contributes to these organizations' funding, and it is difficult to attribute whether their funding should be attributed to the private sector or the MDBs. Keeping these issues in mind, we discuss the climate change financing in the following categories: (i) multilateral development banks and other similar international financial institutions, (ii) United Nations agencies including the Global Environmental Facility, (iii) bilateral and multilateral government funding and (iv) the private sector (private citizens and corporations and philanthropic organizations).

\subsection{Multilateral Development Banks and Other International Development Finance Institutions}

Multilateral Development Banks (MDBs) are the main sources of climate change adaptation financing as well as the main agencies to implement or execute the financing in their client countries. MDBs include six development banks: the World Bank Group (WBG), the Asian Development Bank (ADB), the Inter-American Development Bank (IDB), the African Development Bank (AfDB), the European Bank for Reconstruction and Development (EBRD), and the European Investment Bank (EIB). Table 1 presents a brief introduction of these MDBs.

In 2018, MDBs committed almost USD 13 billion for climate change adaptation, of which USD 12.162 billion (more than 94\%) was from MDBs' own accounts [5]. Figure 1 presents commitments from each MDB for climate change adaptation in 2018. Of the total MDB adaptation financing in 2018, 70\% was investment loans, $9 \%$ were grants, another $9 \%$ was for policy-based financing, and $8 \%$ was result-based financing. Thirty percent of the total allocation went to Sub-Saharan Africa, 24\% to South Asia, 15\% to Latin America and the Caribbean, 13\% to East Asia and the Pacific, and the remaining went to the rest of the developing world. Of the total commitment, $22 \%$ was allocated to energy, transport, and other built environments and infrastructure, $18 \%$ to water and wastewater systems, $17 \%$ 
to crop and food production, $13 \%$ to other agricultural and ecological resources, $23 \%$ to cross-cutting issues, and 5\% to institutional capacity support or technical assistance [5].

Table 1. Multilateral Development Banks (MDBs).

\begin{tabular}{ccccc}
\hline MDBs & World Bank & $\begin{array}{c}\text { Year of } \\
\text { Establishment }\end{array}$ & Introduction & Headquarters \\
\hline $\begin{array}{c}\text { World Bank Group } \\
\text { (WBG) }\end{array}$ & 1946 & $\begin{array}{c}\text { A global, development financing } \\
\text { institute, 189 member countries }\end{array}$ & Washington, DC \\
\cline { 2 - 5 } & $\begin{array}{c}\text { International Financial } \\
\text { Corporation (IFC) }\end{array}$ & 1956 & $\begin{array}{c}\text { Private sector wing of the World } \\
\text { Bank Group }\end{array}$ & Washington, DC \\
\hline Asian Development Bank (ADB) & 1966 & $\begin{array}{c}\text { Regional development Bank for } \\
\text { Asia and the Pacific, } \\
\text { 67 member countries }\end{array}$ & Manila, Philippines \\
\hline African Development Bank (AfDB) & 1964 & $\begin{array}{c}\text { Regional development Bank for } \\
\text { Africa, 80 member countries }\end{array}$ & Tunis, Tunisia \\
\hline $\begin{array}{c}\text { Inter-American Development Bank (IDB) } \\
\text { European Bank for Reconstruction \& } \\
\text { Development (EBRD) }\end{array}$ & 1959 & $\begin{array}{c}\text { Regional development Bank for } \\
\text { Latin America and the } \\
\text { Caribbean, 48 member countries }\end{array}$ & Washington, DC \\
\hline European Investment Bank (EIB) & 1991 & $\begin{array}{c}\text { Regional development Bank for } \\
\text { Eastern Europe and Central Asia, } \\
\text { 65 member countries }\end{array}$ & HQ-London \\
\hline International lending \\
organization of the EU
\end{tabular}

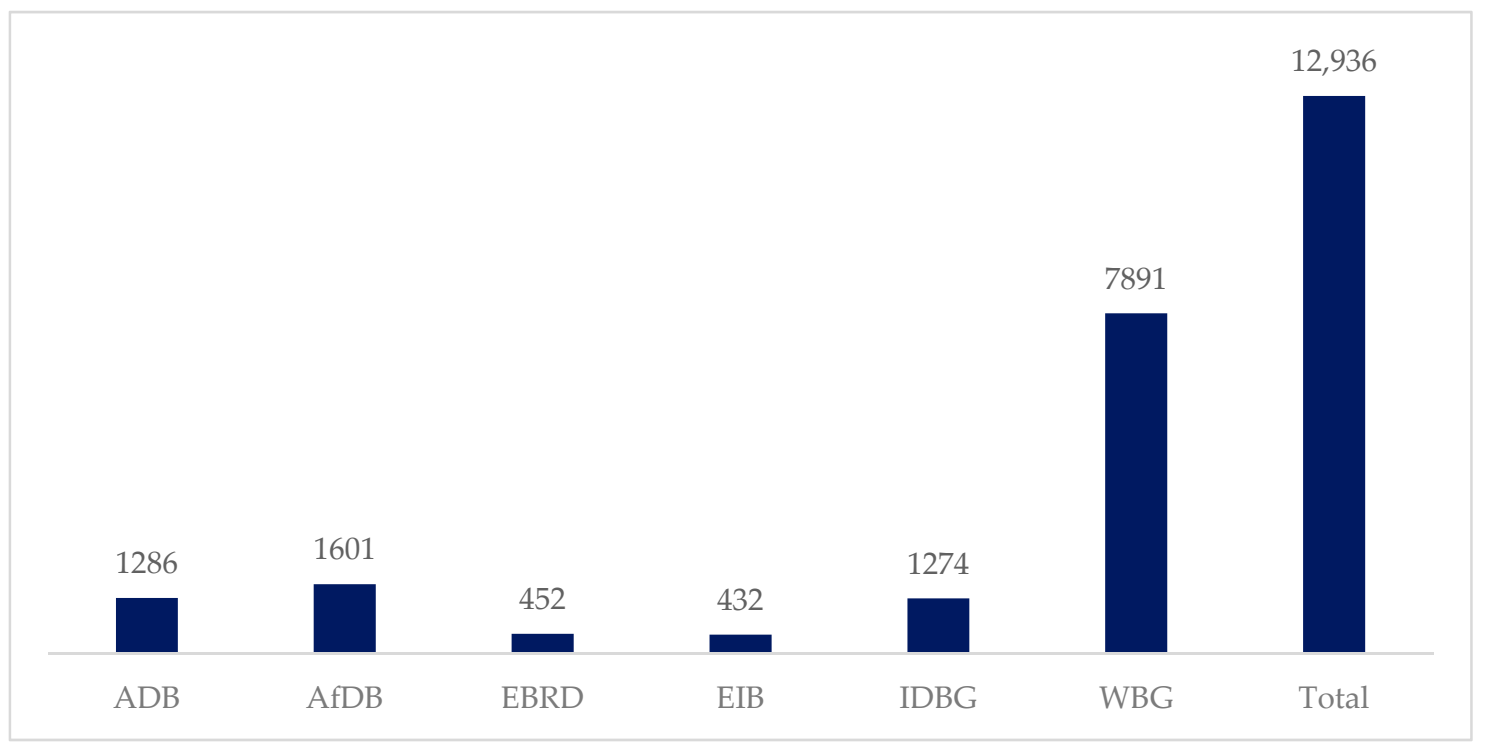

Figure 1. MDBs' commitments for climate change adaptation in 2018. Source: MDB (2019) [5].

MDBs use various funding windows or mechanisms or facilities to finance climate change adaptation. Table 2 presents examples of these windows or mechanisms or facilities. MDBs have launched a large number of windows to finance climate risk reduction and adaptation activities. In most cases, the sources of the funds are contributions from various governments in the form of trust funds to the MDBs. Usual financial instruments of MDBs (grants, soft loans, technical assistance, guarantees, and equity) are also used for climate change adaptation financing. These trust funds leverage additional funding from the MDBs' own budget or from national governments and in some cases the private sector too. 
Table 2. Main funding windows under the MDB for climate change adaptation and resilience.

\begin{tabular}{|c|c|c|}
\hline Name of Fund & $\begin{array}{l}\text { Administrating } \\
\text { MDB }\end{array}$ & $\begin{array}{l}\text { Financing } \\
\text { Instruments }\end{array}$ \\
\hline $\begin{array}{l}\text { Global Facility for Disaster Reduction } \\
\text { and Recovery (GFDDR) }\end{array}$ & World Bank & Grant \\
\hline Global Index Insurance Facility (GIIF) & World Bank and IFC & Worldwide \\
\hline $\begin{array}{l}\text { IDB Regional Fund of Agricultural } \\
\text { Technology (FONTAGRO) }\end{array}$ & IDB & Grant \\
\hline IDB's Infrastructure Fund & IDB & Loan, TA \\
\hline $\begin{array}{l}\text { IDB's Sustainable Energy and Climate } \\
\text { Change Initiative (SECCI) }\end{array}$ & IDB & Grant, TA \\
\hline IFC Partial Credit Guarantees & IFC & Loan, Guarantee \\
\hline Climate Investment Funds (CIF) & World Bank & Different for individual funds \\
\hline IFC Risk Sharing Facility (IFC RSF) & IFC & RSF \\
\hline International Development Association & World Bank & Grant, loan \\
\hline Korea Green Growth Trust Fund & World Bank & Grant, TA \\
\hline $\begin{array}{l}\text { MDB Pilot Program for } \\
\text { Climate Resilience }\end{array}$ & MDB & Grant, loan, TA \\
\hline $\begin{array}{l}\text { Multilateral Investment Fund (MIF) of } \\
\text { the IDB Group }\end{array}$ & IDB & Grant, loan, equity, TA \\
\hline $\begin{array}{l}\text { Partnership for Market } \\
\text { Readiness (PMR) }\end{array}$ & World Bank & Grant \\
\hline $\begin{array}{l}\text { Pilot Program for Climate } \\
\text { Resilience (PPCR) }\end{array}$ & World Bank & Grant, loan \\
\hline $\begin{array}{l}\text { Public-Private Infrastructure Advisory } \\
\text { Facility (PPIAF) }\end{array}$ & World Bank & Grant, TA \\
\hline $\begin{array}{l}\text { World Bank Group Catastrophic } \\
\text { Risk Management }\end{array}$ & World Bank & $\begin{array}{l}\text { Weather hedges contingent } \\
\text { financing }\end{array}$ \\
\hline ADB Climate Change Fund (ADB-CCF) & $\mathrm{ADB}$ & Co-financing, grant, TA \\
\hline Africa Climate Change Fund(ACCF) & AfDB & Grant \\
\hline Africa Water Facility (AWF) & AfDB & $\begin{array}{l}\text { Co-financing, grant, loan risk } \\
\text { management }\end{array}$ \\
\hline ASEAN Infrastructure Fund (AIF) & ADB & Co-Financing, loan, TA \\
\hline
\end{tabular}
Source: [12].

Among the MDBs, the World Bank Group (WBG) leads in terms of the number of financial windows/mechanisms, number of projects, and size of the fund dedicated to climate change adaptation. The Inter-American Development Bank and the African Development Bank have also executed some programs to finance climate change adaptation. However, the Asian Development Bank is lagging behind the other MDBs in terms of climate change adaptation financing; most of ADB's climate finance has gone to climate change mitigation.

Below we highlight some of these funding windows/mechanisms/facilities for the illustrative purpose of understanding their role in financing climate change adaptation activities.

\subsubsection{Global Facility for Disaster Reduction and Recovery (GFDDR)}

The Global Facility for Disaster Reduction and Recovery (GFDRR) is a funding mechanism of the World Bank that finances activities to understand, manage, and reduce risks from natural hazards which are being exacerbated due to climate change. It was established in 2006 and it has provided financial support to over 400 local, national, regional, and international entities to execute climate change adaptation and resilience in developing 
countries more vulnerable to natural disasters. The fund has been contributed to by 37 countries and 11 international organizations. Most of the GFDRR resources are provided as grants to countries to support the implementation of the Sendai Framework. Besides supporting climate change resilience, it also supports enabling gender equality. The GFDRR has been supporting activities in the following eight areas: (i) using science and innovation in disaster risk management, (ii) promoting resilient infrastructure, (iii) scaling up engagements for city resilience, (iv) strengthening hydromet services and early warning systems, (v) deepening financial protection through disaster risk financing and insurance, (vi) building social resilience, (vii) deepening engagements in resilience to climate change, and (viii) enabling resilient recovery. By June 2018, the GFDRR has an active portfolio of USD 252 million, financing 394 activities and 136 countries addressing a range of issues including flooding, earthquakes, and landslides [13].

\subsubsection{The Pilot Program for Climate Resilience (PPCR)}

The Pilot Program for Climate Resilience (PPCR) was conceived in 2008 and has been operational since 2012 (https: / / climatefundsupdate.org/the-funds/pilot-program-forclimate-resilience-2/ accessed on 30 September 2020). Its primary objective is to finance the preparation of climate-resilient national development plans. To achieve its objective, the PPCR provides financing for pilot and demonstration activities and capacity building to enable developing countries to build upon existing national work to integrate climate resilience into national and sectoral development plans. It also provides co-financing to public and private sector investments identified in national or sectoral development plans. Other eligible funding activities include enabling learning-by-doing and knowledge sharing at the country, regional, and global levels. It gives priority to highly vulnerable Least Developed Countries eligible for MDB concessional funds. The PPCR funding instruments include a grant to prepare the Strategic Program for Climate Resilience, a grant up to USD 1.5 million for the preparation of single country pilots, and grants and concessional loans for additional costs necessary to make a project climate-resilient. The World Bank Group is the trustee of the PPCR and all MDBs (except the European Investment Bank) are its implementation agencies. Since it began operations (July 2012), the PPCR has committed USD 985 million for 60 projects in 20 countries or regional groups of countries [14].

\subsubsection{The Global Index Insurance Facility (GIIF)}

The World Bank Group (including the International Financial Corporation, the private sector wing of the World Bank Group) launched the Global Index Insurance Facility (GIIF) in 2009 with funding from the European Union, and the governments of Germany, Japan, and the Netherlands. (https:/ / www.ifc.org/wps/wcm/connect/industry_ext_ content/ifc_external_corporate_site/ accessed on 30 September 2020) The purpose of this index-based insurance facility is to protect smallholder farmers and micro-entrepreneurs against the catastrophic risks of natural disasters, which are expected to be exacerbating due to climate change. This insurance facility is one of the first innovative approaches to address climate change risks. It is different from traditional insurance services as it pays out benefits based on a pre-determined index or loss of assets and investments resulting from weather and catastrophic events, without requiring intermediating entities to assess the claims, thereby making the claims settlement process quicker. This facility also finances activities to promote the concept of innovative insurance solutions, capacity building, technical advice on products and pricing, and to encourage public policy dialogue and regulatory environment facilitation. The GIIF has facilitated more than 4.6 million contracts, with USD 730 million in sums insured, covering approximately 23 million people, primarily in Sub-Saharan Africa, Asia, Latin America, and the Caribbean. (https: / / www.indexinsuranceforum.org/overview accessed on 30 September 2020) 


\subsubsection{African Water Facility (AWF)}

The African Water Facility (AWF) was established in 2004 to mobilize resources to finance water resources development activities in Africa. The main purpose of this fund is to support the equitable and sustainable management of water resources in Africa for economic growth, poverty alleviation, and regional cooperation. The African Development Bank (AfDB) is the implementation or administration agency of this fund. The fund is contributed to by multilateral financial institutions, foundations, and African governments. During the 2006-2018 period, it committed approximately GBP 162 million to 117 projects in 52 countries.

\subsection{UN Agencies for Climate Change Adaptation Finance}

Various UN organizations are either the source or implementation agency for climate change adaptation financing. The Global Environmental Facility (GEF) and the UNFCCC serve both roles. Other UN organizations, such as the United Nations Development Program (UNDP), and the United Nations Environmental Program (UNEP) serve more as implementation agencies of climate change adaptation financing. These institutes utilize different funds created under the UNFCCC (e.g., LDC Fund, Strategic Climate Fund, and Green Climate Fund) and the fund generated by the GEF. Other UN organizations, such as the World Meteorological Organization (WMO), Food and Agriculture Organization (FAO), International Fund for Agricultural Development (IFAD), and the United Nations Capital Development Fund (UNCDF), also finance climate change adaptation activities. Below we briefly introduce these funds and institutions.

\subsubsection{Global Environmental Facility (GEF)}

The Global Environment Facility (GEF) was established in 1992 during the Rio Earth Summit. It provides financial support to almost all international environmental agreements, including the UNFCCC. It is still the sole financial mechanism of the UNFCCC. Besides climate change mitigation and adaptation, the GEF also covers areas related to the protection of forests, biodiversity, land and landscapes, ecological systems, and the management of water resources and wastes. The financial resources under the GEF are contributed to by 183 countries, international financial institutions, non-governmental organizations, and the private sector. The GEF finances only the agreed incremental costs of eligible project activities. Under climate change adaptation and resilience, the GEF finances various activities, including capacity building, demonstration (i.e., pilot) projects, adaptation technology transfer, the development of national adaptation plans, and vulnerability and adaptation assessments. It serves as the secretariat of the climate change adaptation fund established under the Kyoto Protocol. By the year 2018, the GEF had provided over USD 18.1 billion in grants and mobilized an additional USD 94.2 billion in co-financing for more than 4500 projects in 170 countries. (https:/ / www.thegef.org/about-us accessed on 30 September 2020) On climate change adaptation activities alone, the GEF has financed over USD 1.5 billion as grants, and co-financed USD 7 billion with other partners for 330 adaptation projects in 130 countries since 2001. (https:/ / www.thegef.org/topics/climate-change-adaptation accessed on 31 August 2020.)

The GEF has adopted the following three strategies to finance climate change adaptation in developing countries:

- Reduce vulnerability and increase resilience through innovation and technology transfer for climate change adaptation;

- Mainstream climate change adaptation for systemic impact (i.e., climate change activities also address other environmental and sustainable development challenges);

- Foster enabling conditions for effective and integrated climate change adaptation by supporting developing countries to prepare and implement national adaptation plans under the UNFCCC.

The GEF, in fact, contributes funding to various funds, such as the Least Developed Countries Fund (LDCF) and the Special Climate Change Fund (SCCF) discussed later in 
this section. Under the LDCF, it had financed the preparation of NAPAs in 51 countries and provided more than USD 1.16 billion to implement urgent adaptation measures under NAPAs and to assess medium and long-term adaptation needs by 2017. Similarly, under the SCCF, the GEF has financed USD 350 million in 77 projects in 79 countries [15].

\subsubsection{United Nations Framework Convention on Climate Change (UNFCCC)}

The UNFCCC has established various funds to finance climate change activities, including climate change adaptation. Among these, the chief funds for financing adaptation and resilience are the Green Climate Fund (GCF), Adaptation Fund, Special Climate Change Fund and the Least Development Country Fund. The Global Environmental Facility (GEF) has been serving as the financial mechanism of the UNFCCC since the UNFCCC became operational in 1994. The GCF, established in 2011, now acts as an operating entity of the UNFCCC financial mechanism. These funds are briefly discussed in this paper later. A Standing Committee on Finance has been established to govern the funds under the UNFCCC [16].

\subsubsection{United Nations Development Program (UNDP)}

The UNDP is another main UN organization for executing climate finance programs. Its focus, in term of climate change adaptation, is on promoting equitable and pro-poor approaches to build climate-resilient livelihoods. It finances activities to enhance communities' capacity to adapt to the changing climate by contributing to the creation of robust and responsive state institutions, capable public and private sector management, and skilled human resources. It is done through regional, national, subnational, and communitybased programs. To date, it has supported 75 countries, leveraging more than USD 800 million, of which USD 300 million is grants and USD 500 million is co-financing. (UNDP Fact sheet. https:/ / www.undp.org/content/dam/undp/library / corporate/fast-facts / english/FF-Climate-Change-Adaptation.pdf accessed on 30 September 2020) The UNDP has created several windows to finance climate change adaptation, including the following:

- Community-Based Adaptation (CBA), to finance projects in local natural resource management to address climate risk and validate adaptation measures in vulnerable regions and communities;

- The Africa Adaptation Program (AAP), to contribute to increasing resilience to climate change across the African continent;

- National Adaptation Programs of Action (NAPAs), to support the design and implementation of NAPA under the LDC Work Program of the UNFCCC;

- Climate Change and Development-Adapting by Reducing Vulnerability (CC-DARE), to support sub-Saharan African countries to create opportunities for integrating climate change adaptation into national development;

- Climate Change and Disaster Risk Reduction (CC/DRR), to support activities for the strengthening of national capacities to manage climate change risks and adaptation measures, such as the preparation of disaster management legislation, risk assessment, and reduction plans, and the establishment of emergency preparedness networks and early warning systems;

- Adaptation Knowledge Management and Methodology Support, to strengthen the capacity to make decisions under the inherent uncertainties of climate change.

\subsubsection{United Nations Environmental Program (UNEP)}

The United Nations Environmental Program (UNEP) implements several activities for climate change adaptation in developing countries. It finances the following activities [17]:

- Developing methods and tools to help adaptation planning and decision-making, and improving the science-policy interface in adaptation policies and planning;

- Helping countries overcome barriers to implementing their adaptation solutions by improving access to information, facilitating policy development, and easing access to finance; 
- Enhancing climate resilience through planning, piloting, and testing ecosystem-based adaptation (i.e., restoration and sound management of ecosystems and biodiversity);

- Facilitating developing countries' access to climate finance to implement their NAPAs and help advance their adaptation planning and institutional development.

The UNEP's climate change adaptation activities are mostly funded through the Global Environmental Facility (GEF).

The major financial programs that support climate change adaptation through the UN agencies are listed in Table 3.

Table 3. Main funding windows under the UN Agencies for climate change adaptation.

\begin{tabular}{llll}
\hline $\begin{array}{l}\text { Caribbean Catastrophe Risk Insurance } \\
\text { Facility (CCRIF) }\end{array}$ & CCRIF SPC & CARICOM Members & $\begin{array}{l}\text { Short-Term } \\
\text { Liquidity }\end{array}$ \\
\hline GEF Small Grants Program (GEF SGP) & UNDP & $\begin{array}{l}\text { NGO/CBO working GEF } \\
\text { focal areas }\end{array}$ & Grant \\
\hline $\begin{array}{l}\text { GEF Trust Fund-Climate Change focal } \\
\text { area (GEF 6) }\end{array}$ & GEF & $\begin{array}{l}\text { Countries eligible for WBG } \\
\text { UNDP financing/TA }\end{array}$ & Grant \\
\hline $\begin{array}{l}\text { Green Climate Fund (GCF) } \\
\text { IFC Partial Credit Guarantees (IFC PCG) }\end{array}$ & IFC & $\begin{array}{l}\text { All developing country parties to } \\
\text { the UNFCCC }\end{array}$ & $\begin{array}{l}\text { Grant, concessional loan } \\
\text { guarantees Equity }\end{array}$ \\
\hline $\begin{array}{l}\text { Least Developed Countries Fund (LDCF) } \\
\begin{array}{l}\text { Pilot Program for Climate } \\
\text { Resilience (PPCR) }\end{array}\end{array}$ & $\begin{array}{l}\text { In accordance with IFC } \\
\text { investment guidelines }\end{array}$ & Loan guarantee \\
\hline $\begin{array}{l}\text { Special Climate Change Fund (SCCF) } \\
\text { SCF supplement }\end{array}$ & GEF & Oll LDC parties to UNFCCC & Grant \\
\hline $\begin{array}{l}\text { UNFCCC Adaptation } \\
\text { Fund (UNFCCC AF) }\end{array}$ & UNFCCC & $\begin{array}{l}\text { All developing country parties } \\
\text { to UNFCCC }\end{array}$ & Grant, Loan \\
\hline $\begin{array}{l}\text { Adaptation for Smallholder Agriculture } \\
\text { Program (ASAP) }\end{array}$ & IFAD & parties to the Kyoto Protocol & Grants \\
\hline
\end{tabular}

Source: [12].

\subsubsection{UNFCCC Adaptation Fund}

The Adaptation Fund was established under the Kyoto Protocol of the UNFCCC. The primary source of the fund is the two percent share of proceeds of the Certified Emission Reductions (CERs) issued under CDM projects. National governments and the private sector also contribute to this fund. The principal objective of the Adaptation Fund is to finance climate change adaptation activities in the vulnerable communities of developing countries. Since 2010, USD 564 million has been committed from this fund to 84 climate adaptation project activities. (https:/ / www.adaptation-fund.org/about/ accessed on 30 September 2020) The World Bank Group (WBG) has been serving as the interim trustee for the Adaptation Fund. Most of the projects financed by this fund, however, have been implemented through the UN agencies. The Adaptation Fund has also launched a 'Readiness Program for Climate Finance' to help strengthen the capacity of national and regional implementing entities to receive and manage climate financing. (https://www.adaptation-fund.org/readiness/ accessed on 30 September 2020).

\subsubsection{UNFFC's Least Developed Country Fund (LDCF)}

This fund was established in 2001 under the UNFCCC to support its least developed country parties for their specific needs related to climate change adaptation. It is used for mainly two purposes: (i) to implement urgent adaptation measures in countries vulnerable to climate change, and (ii) to help least developed countries prepare their National Adaptation Programs of Action (NAPAs), which consist of the identification and implemen- 
tation of strategies to adapt to climate change. It fully finances or co-finances adaptation activities which are focused on community-level activities. The LDCF is contributed to by 194 governments around the world, international institutions, and the private sector. It is administered by the GEF. At present, the LDCF finances the major climate change adaptation project activities in the most vulnerable countries in the world. By 2017, the LDCF had financed NAPAs in 51 LDCs [18].

\subsubsection{UNFCCC's Special Climate Change Fund (SCCF)}

The Special Climate Change Fund (SCCF) was established by the Seventh Conference of the Parties (COP7) to the UNFCCC held in Marrakech, Morocco in 2001. It finances both long-term and short-term activities to improve climate resilience in water resources management, land management, agriculture, health, infrastructure development, fragile ecosystems, which include mountainous ecosystems and integrated coastal zone management areas [17]. The financing is provided through two windows: the Adaptation window (Special Climate Change Fund-A) and (ii) the Technology Transfer window (Special Climate Change Fund-B). While the first window is relevant to climate change resilience activities, the second window can also be used if technology transfer is related to climate change adaptation. The fund also finances activities to improve climate resilience in the healthcare sector by providing funding for the monitoring of diseases and vectors affected by climate change. It also finances activities to develop early warning systems. Capacity building for preparing and preventing climate change-related disasters (e.g., droughts and floods) is also covered by this fund. It also finances capacities to develop catastrophe risk insurance systems. The technology transfer component does not only cover implementing already proven technologies but also developing new technologies through research and development. It also funds demonstrations of project implementation (pilot projects) and knowledge hubs (e.g., regional centers and networks) working in the field of climate change adaptation. The priority areas of funding are determined by the GEF based on the guidance provided by the UNFCCC. The total size of the SCCF funding by 2018 was USD 350 million, and it has financed 77 projects in 79 countries. (https://www.thegef.org/topics/special-climate-change-fund-sccf accessed on 30 September 2020).

\subsubsection{UNFCCC's Green Climate Fund (GCF)}

The Green Climate Fund (GCF) was established by the UNFCCC during the 10th Conference of Parties (COP 10) held in Cancun, Mexico in 2010. Its main objective is to help developing countries limit or reduce their GHG emissions and adapt to climate change. After the Paris Climate Accord agreed in Paris in 2015, the GCF has been seen as the main financial vehicle to achieve the Paris Agreement. GCF initially gathered pledges worth USD 10.3 billion, mostly from developed countries but also from some developing countries, regions, and one city (Paris); by 2020, the size of the fund is expected to be USD 100 billion [17]. The UNFCCC directly administers the fund through a Standing Committee on Finance (UNFCCC SCF). The activities eligible for GCF funding are those aligned with the priorities of recipient countries and fully owned by recipient countries. National and sub-national entities can directly access the fund without needing to go through international intermediaries. The GCF balances its portfolios (50:50) between climate change mitigation and adaptation. It pays particular attention to the needs of countries that are highly vulnerable to climate change (e.g., the Least Developed Countries, Small Island Developing States, and the African States). Fifty percent of the total adaptation portfolios will be implemented in these vulnerable regions.

Financing for the GCF can be in the form of grants, loans, equity, or guarantees. While the fund has been initially contributed by the public sector (governments), it aims to generate financing from the private sector by stimulating them to directly participate in climate change projects through equity or by other means. It will create a Private Sector Facility (PSF) for this purpose. 


\subsubsection{UNCDF's Local Climate Adaptive Living Facility (LoCAL)}

The UN Capital Development Fund (UNCDF) established the Local Climate Adaptive Living Facility (LoCAL) in 2012 to integrate climate change adaptation into the community or local development of developing countries [17]. It contributes to local governments' planning and budgeting systems to incorporate awareness and improve resilience to climate change. By nature, these are typically small- to medium-sized investments for climate change adaptation and resilience. The main financial instruments under the LoCAL are performance-based grants. The fund finances several activities, such as (i) enabling local authorities to assess climate risks, (ii) integrating adaptation into local development planning and budgeting, and (iii) implementing selected adaptation interventions. The LoCAL is co-financed by the Global Climate Change Alliance of the European Union (GCCA-EU), and by the Swedish International Development Agency (SIDA). Since its establishment in 2012, it has financed about USD 9 million in 64 local governments in 13 countries around the world [19].

\subsection{Bilateral and Multilateral Financing by National Governments}

National governments, particularly developed countries, are the key sources of climate change adaptation finance in developing countries, through bilateral and multilateral channels. Since this paper deals with international financing for climate change adaptation focusing on developing countries, it does not address the financing of climate change adaptation through national funding in developed countries. Some developing countries have also established national funds for climate adaptation, but those funds are contributed to by developed countries through bilateral or multilateral channels. For example, Rwanda established its national climate fund, FONERWA, through contributions from the UK's Department for International Development (DFID), KfW Germany, the Green Climate Fund, World Bank, and African Development Bank. Domestic sources such as dedicated government revenues collected through environmental fines and fees (e.g., forestry and water usage fees) also contributed to this fund. Similarly, Ethiopia created its Climate Resilient Green Economy Facility (CRGE Facility) through contributions from the UK DFID, Adaptation Fund, Green Climate Fund, and also from bilateral contributions from the governments of Norway, Austria, and Denmark.

It should be noted here that developed countries are the major contributors to the climate change adaptation funds established and administrated by international organizations, such as UN organizations and MDBs, among others. These funds were discussed earlier in this paper; here our focus is on bilateral or multilateral funds directly provided by donor countries for recipient countries. This means that government or non-governmental organizations of the recipient countries directly access these funds. There are a large number of bilateral or multilateral funds established by developed countries to finance climate change adaptation activities in developing countries. Table 4 presents some of these funds. Note that this table does not present an exhaustive lists of such funds; it presents key funds for illustrative purposes. 
Table 4. Key Bilateral and Multilateral Funds Established by Developed Countries to Finance Climate Change Adaptation in Developing Countries.

\begin{tabular}{|c|c|c|}
\hline Name of Fund & Administered by & Focus \\
\hline $\begin{array}{l}\text { Canada Fund for African Climate } \\
\text { Resilience (CFACR) }\end{array}$ & Canadian government & Sub-Saharan Africa \\
\hline $\begin{array}{l}\text { Caribbean Catastrophe Risk Insurance } \\
\text { Facility (CCRIF) }\end{array}$ & CCRIF SPC & CARICOM members \\
\hline $\begin{array}{l}\text { Climate and Development Knowledge } \\
\text { Network (CDKN) }\end{array}$ & $\begin{array}{l}\text { Governments of Netherlands and } \\
\text { United Kingdom }\end{array}$ & Developing countries \\
\hline Climate Insurance Fund (CIF) & KfW, BlueOrchard & $\begin{array}{l}\text { Qualified insurance and } \\
\text { reinsurance companies }\end{array}$ \\
\hline Danish Climate Investment Fund (KIF) & $\begin{array}{l}\text { Investment Fund for Developing } \\
\text { Countries (IFU) }\end{array}$ & $\begin{array}{l}\text { Activities that contain a Danish } \\
\text { economic interest }\end{array}$ \\
\hline $\begin{array}{l}\text { Energy and Environment } \\
\text { Partnership (EEP) }\end{array}$ & Finland-Ministry of Foreign Affairs & $\begin{array}{l}\text { NGOs, public and private companies, } \\
\text { research and education institutions }\end{array}$ \\
\hline Japan's Fast Start Finance (JFSF) & Japanese Ministry of Finance & Developing countries \\
\hline KfW Development \& Climate Finance & KfW & $\begin{array}{l}\text { Public and private entities } \\
\text { Depending on contract }\end{array}$ \\
\hline $\begin{array}{l}\text { Germany's International Climate } \\
\text { Initiative (IKI) }\end{array}$ & Ministry for the Environment & Projects in IKI's areas of support \\
\hline $\begin{array}{l}\text { Global Climate Change } \\
\text { Alliance }+(\text { GCCA }+)\end{array}$ & European Union & $\begin{array}{l}73 \text { LDCs or SIDS that are recipients of } \\
\text { official development assistance }\end{array}$ \\
\hline International Climate Fund (UK)(ICF) & DFID, DECC, Defra & $\begin{array}{l}\text { Projects consistent with the DAC } \\
\text { definition of ODA }\end{array}$ \\
\hline $\begin{array}{l}\text { International Climate Initiative } \\
\text { (Germany) (ICI) }\end{array}$ & Ministry for the Environment & $\begin{array}{l}\text { Developing and newly industrializing } \\
\text { countries, countries in transition }\end{array}$ \\
\hline Nordic Climate Facility (NCF) & NEFCO & $\begin{array}{l}\text { Entities registered in Denmark, Finland, } \\
\text { Iceland, Norway or Sweden }\end{array}$ \\
\hline $\begin{array}{l}\text { US Global Climate Change } \\
\text { Initiative (GCCI) }\end{array}$ & USAID and the U.S. Treasury & Developing countries \\
\hline
\end{tabular}

Source: [12].

\subsubsection{The Global Climate Change Alliance Plus (GCCA+)}

The Global Climate Change Alliance Plus (GCCA+) was established in 2008 by the European Union to help the world's most vulnerable countries to increase their resilience to climate change by reducing climate change risks and by adapting to climate change impacts (http:/ / www.gcca.eu/about-gcca accessed on 30 September 2020). Small Island Developing States (SIDS) and Least Developed Countries (LDCs) are the priority recipients of this fund. It funds multi-year programs with an average contribution of EUR 5 million per project, in line with national priorities for climate-resilient actions identified by EU Delegations with local development agents. It also finances facilities that support EU Delegations and development partners to implement GCCA+ projects. Moreover, also eligible for GCCA+ financing are regional and multi-country programs that supplement existing project activities. The fund is accessible to local level communities and local authorities. For example, it complements funding of the United Nations Capital Development Funds' LoCAL initiative. Since it began operation in 2008, the GCCA+ fund has supported over 70 national programs in LDC and SIDS. Since 2016, the GCCA+ fund has also started to support middle-income countries. GCCA+ commitments amounted to EUR 750 million for the 2007-2020 period. (http: / / www.gcca.eu/funding/how-does-gcca-funding-work accessed on 30 September 2020). 


\subsubsection{Germany's International Climate Initiative}

The International Climate Initiative (IKI, German abbreviation) was established by the German Federal Ministry for the Environment, Nature Conservation and Nuclear Safety (BMU) in 2008 to finance climate change and biodiversity projects in developing, newly industrializing countries and economies in transition. (https:/ / www.international-climateinitiative.com/en/ accessed on 30 September 2020) Initially, part of the proceeds from EUETS auctioning allowances contributed to this fund. Later Germany's Special Energy and Climate Fund started to contribute to it. It is Germany's main funding window to finance Germany's commitments under the UNFCCC and the UN Framework Convention on Biological Diversity. It funds climate change mitigation and adaptation to climate change, conservation of natural carbon sinks through reducing emissions from deforestation and forest degradation (REDD+), and conservation of biodiversity. Like other international funds for financing climate change adaptation, it also prioritizes activities in vulnerable countries and regions. The key areas supported by this fund are ecosystem-based adaptation, climate-related extreme event risk management (e.g., insurance solutions), and the development and implementation of national adaptation strategies. By 2017, it had financed more than 100 climate change adaptation projects.

\subsubsection{The ClimDev-Africa Special Fund (CDSF)}

The CDSF is a multi-donor trust fund established to support African countries, institutions, and communities to build climate change resilience. It has been operational since 2014. It provides financing for (i) the development, dissemination, and utilization of high-quality information related to climate change risks; (ii) capacity development of policymakers and support institutions; (iii) pilot adaptation practices that demonstrate the integration of climate change adaptation into development planning and practices. (https://www.afdb.org/fileadmin/uploads/afdb/Documents/GenericDocuments/CDSF_at_a_glance_web.pdf accessed on 30 September 2020). It has been jointly implemented by the African Union Commission (AUC), the African Development Bank, and the United Nations Economic Commission for Africa (UNECA). The CDSF has financed EUR 33 million in national and regional projects in areas such as effective weather monitoring and early warning systems in several African countries, building disaster resilience to natural hazards at the Sub-Saharan African Region, country, and community levels.

\section{Private Sector and Financing Climate Resiliency}

The private sector is another important source of financing for climate-resilient projects. International organizations, including the UNFCCC, have urged and encouraged the private sector to finance climate-resilient projects. The public-private partnership schemes launched by various countries and supported by international development partners could provide a strong platform for the private sector to finance climate resiliency [20]. Several studies, such as Micale et al. (2018) [20], Agrawala et al. (2011) [21], Atteridge (2011) [22], Venugopal et al. (2012) [23], Pauw (2014) [24], and UNEP (2016) [25] discuss how the private sector could finance climate change adaptation and resilience-related activities and projects. Micale et al. (2018) highlight the barriers to the private sector actively participating in adaptation financing. These barriers include uncertainty regarding returns on investment, high upfront costs of technology, and a lack of technical and institutional capacities in the project hosts [20]. Agrawala et al. (2011) explore new business opportunities for private companies to motivate them for their engagement in adaptation financing [21]. Atteridge (2011) argues that private sector financing for adaptation often does not match developing countries' most pressing needs [22]. Venugopal et al. (2012) examine the ways of leveraging private finance for climate change adaptation through public funds [23]. Pauw (2014) finds that the evidence for private sector engagement in climate change adaptation is weak in developing countries [24]. UNEP (2016) illustrates various mechanisms for enhancing 
private sector financing for climate change adaptation and also highlights policies needed to incentivize the private sector [25].

Before going deeper to analyze how the private sector could or should finance climate resiliency, it is important to understand the incentives and obligations that can encourage the private sector to finance climate change adaptation and resilience. By definition, the private sector is a profit-making economic entity. Its actions are mainly driven by financial incentives or regulatory mandates/obligations. To some extent, their actions are also driven by social obligations (goodwill hunting). A private sector entity finances a project if it expects the project to deliver a certain rate of returns to its investors. However, most project activities that will be impacted by climate change produce public goods (e.g., roads, bridges, parks, irrigation systems, electricity supply systems). Normally, the private sector may not find adequate incentives to invest in these public goods and services in a normal or business-as-usual situation. When these systems become more vulnerable due to climate change, this provides further disincentives to the private sector to invest in them.

Nevertheless, the private sector might invest in climate change resilient activities if it has enough confidence the assets it owns are vulnerable to climate change. For example, a private firm making a large-scale investment in agriculture farming could be interested in reducing weather-related risks (drought, flooding). It could invest in reducing this risk. Now, if the firm has reasonable confidence that climate change might aggravate risks, it may be interested in making an additional investment to reduce these risks, provided that the return from its farming is still meeting its expectations. If the private sector finds that the investment is too high for mitigating these risks and it fears not making a reasonable rate of return from the farming, it will move away from this business and invest somewhere else where it sees lower risks and reasonable returns.

The private sector finances climate change adaptation and resilience through various channels. It directly contributes to the UN funding windows, such as the Adaptation Funds and LDC funds. It also co-finances climate change adaptation and resilience activities along with the MDBs. The UNFCCC's Green Climate Fund is planning to leverage private investment in climate change adaptation. The private sector also contributes through philanthropic organizations or institutions. Bill Gate is a co-leader of the Global Commission on Adaptation created in 2018 to catalyze global climate financing in climate change adaptation and resilience. Thus, an appropriate methodology does not yet exist to track and report private financing of climate change adaptation and resilience [20]. Moreover, no regulations that require the private sector organizations to monitor and disclose their actions related to climate change exists [25].

Accounting for the private sector's contribution to climate change adaptation is also complex because some might argue that most climate change adaptation is coming from the private sector. This is because when governments finance these activities directly or through international development institutions, the source of funds ultimately comes from the taxation of private households or businesses. Moreover, ultimately it would be the private sector that purchases various financial instruments (e.g., green bonds or any other climate change-oriented bonds) or that makes equity investments in climate change adaptation project activities. Below we present two examples of the private sector's participation in climate change adaptation financing.

It is also argued in some existing studies (e.g., [20]) that small-scale private sector entities (e.g., smallholder farmers, small-and-medium-sized firms) and large-scale entities (multinational firms with complex supply chains) will finance climate change adaptation and resilience activities, particularly in vulnerable sectors such as agriculture. This is true; they have been doing so to reduce weather- or disease-related risks, and they have to increase their investment to reduce the relevant risks if climate change aggravates these risks. While large-scale private firms might be able to afford to invest against climate risks, small-scale private firms may not able to do so. They need help from the public sector (governments) or from the private firms who supply their products (e.g., smallholder coffee farmers who supply cocoa to large coffee manufacturing firms). If larger firms do not 
provide finances to smallholder farmers, there could be a huge risk of disruption in their supply chains, which might cause huge losses.

The private sector (individual or firm) does not have an alternative to invest in climate change resiliency for the assets it owns if the government makes this obligatory through policies and mandates. For example, if governments have different standards for buildings in more vulnerable areas (e.g., coastal areas), a private building owner will make the extra investment to follow these standards. In the absence of incentives and regulations, it may not be reasonable to expect the private sector to invest in climate resiliency. There are many methods governments or international communities can use to provide incentives for the private sector to invest in climate resiliency $[20,24,25]$.

\subsection{Financial Instruments}

While the private sector may not be interested in investing in climate-resilient projects that produce public services, governments can develop financial instruments for private funds and utilize those funds for climate change adaptation and resilience. For example, a government or an international financial institution can issue a bond dedicated to climate change adaptation and resilience to attract private finance, and then use these for climateresilient project activities. If private entities (households, firms, institutions) find the bond attractive to invest in, they will. For example, the World Bank has issued more than USD 13 billion equivalent in Green Bonds through more than 150 transactions in 20 currencies. (https:/ /www.worldbank.org/en/news/immersive-story/2019/03/18/10-yearsof-green-bonds-creating-the-blueprint-for-sustainability-across-capital-markets accessed on 30 September 2020). Of the total investment (commitment) during the 2008-2018 period, $22 \%$ went to climate change adaptation and resilience projects in developing countries around the world [26]. A large number of countries, including the UK, USA, France, China, India, Indonesia, Russia, Germany, and South Korea, have issued green bonds for financing climate change activities, including adaptation and resilience activities. CPI (2018) [27] reports that by the year 2018, the total size of the climate-aligned bond was USD 1.45 trillion. While green bonds or any other bonds dedicated to climate finance attract private finance, they are issued by international financial institutions (e.g., the World Bank's green bonds) or by governments; they might, therefore, be interpreted as climate financing by the issuing institutions or governments rather than actual investors (private sectors).

\subsection{Co-Financing/Guarantees}

Co-financing/guarantees is another mechanism that attracts the private sector to invest in climate change adaptation and resilience projects. For example, if governments or development partners, such as MDIs, cover part of the funding of a climate-resilient project (e.g., a hydropower project with adaptation measures for climate-related risks), the private sector would not have difficulty in financing climate change adaptation activities in the same manner it does for any normal project (i.e., a project without climate change adaptation). Such a project would be more attractive to a private investor because climate change-related risks are covered by the public sector (governments or international donors). The question, however, is if such investment can be interpreted as climate change resilience investment from the private sector. There is a tradition in most existing studies discussing climate change adaptation financing that the entire investment in a project that faces climate change-related risks is attributed to climate change adaptation finance. Climate change adaptation finance is the additional finance (not the entire finance) that is needed in the project due to climate change risks. For example, an investment to control damage from a monsoon flood that occurs each year in South Asian countries cannot be interpreted as a climate change adaptation investment. Climate change adaptation investment would be an incremental investment to control the damage from increased monsoon floods caused by climate change. However, that is not the practice used to interpret climate change adaptation and resilience investment and financing reported to date. 


\subsection{Insurance}

Although climate change is bad for society as a whole, it can provide business opportunities to some. This is similar to the fact that some natural disasters provide business opportunities to some entrepreneurs. For example, when a flood destroys a road or bridge, cement manufacturers might see that their demand goes up. Climate change risks could provide an incentive to insurance companies covering natural disaster damages or weatherrelated crop damages. There are many types of insurance products that cover climate change risks. The most commonly used in the agriculture sector is weather-index insurance. This insurance system first develops a weather index, say, based on rainfall. If there occurs a loss of crops due to heavy rainfall, farmers can claim compensation through their insurance policy. Under climate risk scenarios, insurance providers could increase the premium. Problems of moral hazard (false claims) can be avoided through a high deductible. This type of insurance policy can protect farmers from climate risks; at the same time, it attracts private investors to new types of insurance businesses (climate insurance businesses). The private sector's participation in climate risk insurance has already started in developing countries. Guy Carpenter LLC, one of the leading global risk and reinsurance private firms with 60 offices around the world, provided weather index insurance to smallholding cotton and maize farmers in Mozambique [25].

There exists some private funds that finance climate change adaptation through insurance. One of such funds is the InsuResilience Investment Fund. It was formerly known as the Climate Insurance Fund and was established in 2015 by the German Development Bank, KfW, to contribute to climate change adaptation and resilience by providing an innovative solution in the field of climate risk insurance. It aims to reduce the vulnerability of micro, small and medium enterprises (MSME) and low-income households to extreme weather events. It has been formulated under a public-private-partnership setup. The private sector has two windows: debt and equity investment windows. It also provides technical assistance on insurance product design and development. Moreover, it also provides subsidies on premium payments for the end-clients, but the subsidy provision is temporary and the amount is limited. The fund is meant for existing or new insurance or reinsurance companies interested in insurance solutions to help clients mitigate climaterelated risks. The fund is managed by BlueOrchard, which is a leading global impact investment manager which has invested across 80 emerging and frontier markets around the world. Technical assistance under this fund is managed by CelsiusPro, which is a Swiss-based weather and climate change insurance specialist.

\section{Conclusions}

Adapting to climate change or marching towards a climate-resilient development path is the main strategy to address global climate change. The importance of this strategy is based on two factors. First, despite more than 30 years of negotiation on climate change, there is still no concrete agreement to reduce GHG emissions and stabilize their concentration. While the Paris Climate Agreement has set a goal to stabilize the concentration at the level that does not allow the earth's mean surface temperature to increase above 2 degrees Celsius or even 1.5 degrees Celsius from the pre-industrialized level, the agreement itself is voluntary. Moreover, major emitters such as the United States, Brazil, and Australia have either stayed out of this agreement or do not seem that serious about the agreement. After all, the Paris Agreement is a voluntary deal; there is no guarantee that climate change mitigation pledges made by various countries under this agreement will be met. Second, recent trends or patterns of extreme weather events in terms of their intensities or frequencies indicate that climate change might have already started to show its impacts (USGCRP, 2018, World Bank, 2019).

One of the big challenges of adapting to climate change is that the countries which are most vulnerable to climate change (i.e., least developed countries, small island states) neither have the financial resources nor technical and institutional capacities to adapt to climate change. Existing studies estimate that climate change adaptation will require 
hundreds of billion dollars of investment each year in the next decade. While this amount is small when compared to global economic output (GDP), the asymmetric distribution of climate change impacts (i.e., higher impacts on countries with a lower capacity to cope with it), does not leave an alternative to building a globally cooperative action to finance climate change adaptation activities. In this regard, the international development financial institutions, relevant agencies of the United Nations, donor countries, and even the private sector or philanthropic organizations, are playing a role in establishing various funds to finance climate change adaptation project activities.

Among international development financial institutions, multilateral development banks have launched a large number of funding windows by blending their finances with donor countries' contributions and, to some extent, the private sector's contributions. In addition to MDBs, various funds or financial facilities have been developed under the United Nations to support climate change adaptation activities. Chief among them is the Global Environmental Facility, the principal financial mechanism to support the implementation of environmental agreements reached since the Rio Earth Summit in 1992. Other UN funds include the Green Climate Fund, Least Developed Country Fund, Adaptation Fund, and the Special Climate Change Fund, all set up under the UNFCCC. UN organizations, particularly the United Nations Development Program and the United Nations Environmental Program, are actively involved in mobilizing these funds to implement climate change adaptation programs and policies. Many countries, especially developed countries, are directly contributing, through their overseas development agencies, to financing climate change adaptation activities in developing countries vulnerable to climate change. They are also the main development partners that contribute to the funds set up by the multilateral development banks and UN agencies to finance climate change adaptation.

Since the private sector is the primary source of finances, development communities are exploring innovative ways to engage the private sector to finance climate change adaptation activities. One of the big challenges to engage the private sector on climate change adaptation finance is that the private sector is a profit-making entity and climate change adaptation falls under the good public category. Therefore, unlike in climate change mitigation activities (e.g., clean energy projects), climate change adaptation activities do not offer direct incentives to the private sector. Nevertheless, some innovative solutions or instruments to address this issue are being developed. Climate change bonds attractive to the private sector but dedicated to climate change adaptation could be a solution to channel private finance to climate change adaptation and resilience. Innovative insurance products against climate change impacts, such as weather index insurance, could be developed by private sector-owned insurance companies. Like in the clean energy project activities, the private sector might be interested in financing infrastructure project activities (e.g., power plants, transmission lines, roads, ports, bridges) as long as governments or donors provide guarantees on their expected rate of return on their investments.

This paper presents an overview of various funds available for climate change adaptation in developing countries. There are a large number of issues related to the financing of climate change adaptation. Some of them are the distribution of the funds, the mechanisms of fund allocations, the performance of the funds, and the impacts of adaptation financing. There might be many other issues. Each of these issues deserves separate in-depth analysis. Some of these analyses already exist and many more are expected to come in the future.

Funding: This research received no external funding.

Institutional Review Board Statement: Not applicable.

Informed Consent Statement: Informed consent was obtained from all subjects involved in the study.

Data Availability Statement: Not applicable.

Conflicts of Interest: The authors declare no conflict of interest. 


\section{References}

1. United Nations (UN). United Nations Framework Convention on Climate Change; Climate Change Secretariat: Bonn, Germany, 1992.

2. U.S. Global Change Research Program (USGCRP). Climate Science Special Report: Fourth National Climate Assessment; USGCRP: Washington, DC, USA, 2018; Volume I.

3. World Bank. The World Bank Group Action Plan on Climate Change Adaptation and Resilience; World Bank: Washington, DC, USA, 2019.

4. Hallegatte, S.; Rentschler, J.; Rozenberg, J. Lifelines: The Resilient Infrastructure Opportunity; Sustainable Infrastructure Series; World Bank: Washington, DC, USA, 2019.

5. Multilateral Development Banks (MDB). 2018 Joint Report on Multilateral Development Banks' Climate Finance. 2019. Available online: www.ebrd.com/2018-joint-report-on-mdbs-climate-finance (accessed on 25 October 2020).

6. Watson, C.; Schalatek, L. Climate Finance Fundamentals 3-Climate Finance Thematic Briefing: Adaptation Finance. Heinrich Boll Stiftung North America. 2019. Available online: https:/ / climatefundsupdate.org/wp-content/uploads/2019/03/CFF3-201 8-ENG.pdf (accessed on 15 July 2020).

7. House of Commons International Development Committee (HC-IDC). UK Aid for Combating Climate Change: Eleventh Report of Session 2017-2019. 2019. Available online: https:/ / publications.parliament.uk/pa/cm201719/cmselect/cmintdev/1432/1432 pdf (accessed on 25 July 2020).

8. Chambwera, M.; Heal, G.; Dubeux, C.; Hallegatte, S.; Leclerc, L.; Markandya, A.; McCarl, B.A.; Mechler, R.; Neumann, J.E. 2014: Economics of Adaptation. In Climate Change 2014: Impacts, Adaptation, and Vulnerability. Part A: Global and Sectoral Aspects. Contribution of Working Group II to the Fifth Assessment Report of the Intergovernmental Panel on Climate Change; Field, C.B., Barros, V.R., Dokken, D.J., Mach, K.J., Mastrandrea, M.D., Bilir, T.E., Chatterjee, M., Ebi, K.L., Estrada, Y.O., Genova, R.C., et al., Eds.; Cambridge University Press: Cambridge, UK; New York, NY, USA, 2014; pp. 945-977.

9. United Nations Framework Convention on Climate Change (UNFCCC). Investment and Financial Flows to Address Climate Change; UNFCCC: Bonn, Germany, 2007.

10. World Bank. Economics of Adaptation to Climate Change: Synthesis Report; World Bank: Washington, DC, USA, 2010.

11. United Nations Environmental Program (UNEP). Climate Change Adaptation Gap Report; UNEP: Nairobi, Kenya, 2016.

12. Climate Fund Inventory Database (CFID). Online Climate Fund Inventory Database Maintained by OECD Secretariat. 2019. Available online: https:/ / www.oecd.org/environment/cc/database-climate-fund-inventory.htm (accessed on 12 September 2020).

13. Global Facility for Disaster Reduction and Recovery (GFDRR). Annual Report 2018; World Bank: Washington, DC, USA, 2019.

14. Climate investment Fund (CIF). CIF Disbursement Report. 2019. Available online: https://www.climateinvestmentfunds.org/ sites/cif_enc/files/meeting-documents/joint_ctf_scf_21_inf_2_cif_disbursement_report_1.pdf (accessed on 12 November 2020).

15. Global Environmental Facility (GEF). Financing Adaptation to Climate Change; GEF: Washington, DC, USA, 2017; Available online: https:/ / www.thegef.org/sites/default/files/publications/GEF_\%20AdaptationCOP23_CRA.PDF (accessed on 12 November 2020).

16. UNFCCC Standing Committee on Finance (UNFCCC SCF). 2018 Biennial Assessment and Overview of Climate Finance Flows: Technical Report; UNFCCC: Bonn, Germany, 2018.

17. United Nations Environmental Program (UNEP). Climate Change Adaptation_Fact Sheet; UNEP: Nairobi, Kenya, 2019.

18. Global Environmental Facility (GEF). Financing Adaptation Action: Least Developed Countries Fund and Special Climate Change Fund; GEF: Washington, DC, USA, 2012.

19. United Nations Capital Development Fund (UNCDF). Financing Local Adaptation to Climate Change: Experiences with Performance-Based Climate Resilience Grants. 2017. Available online: https:/ / www.uncdf.org/ (accessed on 12 November 2020).

20. Micale, V.; Tonkonogy, B.; Mazza, F. Understanding and Increasing Finance for Climate Adaptation in Developing Countries. Climate Policy Initiative. 2018. Available online: www.climatepolicyinitiative.org (accessed on 20 December 2020).

21. Agrawala, S.; Carraro, M.; Kingsmill, N.; Lanzi, E.; Mullan, M.; Prudent-Richard, G. Private Sector Engagement in Adaptation to Climate Change: Approaches to Managing Climate Risk; OECD Environment Working Papers, No. 39; OECD: Paris, France, 2011.

22. Atteridge, A. Will Private Finance Support Climate Change Adaptation in Developing Countries? Historical Investment Patterns as a Window on Future Private Climate Finance; Stockholm Environment Institute: Stockholm, Sweden, 2011; Working Paper.

23. Venugopal, S.; Srivastava, A.; Polycarp, C.; Taylor, E. Public Financing Instruments to Leverage Private Capital for Climate-Relevant Investment: Focus on Multilateral Agencies; World Resources Institute: Washington, DC, USA, 2012.

24. Pauw, W. Not a panacea: Private-sector engagement in adaptation and adaptation finance in developing countries. Clim. Policy 2014, 15, 583-603. [CrossRef]

25. United Nations Environmental Program (UNEP). Demystifying Adaptation Finance for the Private Sector; UNEP: Nairobi, Kenya, 2016.

26. World Bank. Green Bond Impact Report 2018; World Bank: Washington, DC, USA, 2018.

27. Climate Policy Initiative (CPI). Global Climate Finance: An Updated View. 2018. Available online: www.climatepolicyinitiative. org (accessed on 12 November 2020). 